\title{
Gram-positive, motile, cluster-forming cocci as a cause of urinary infection
}

\author{
S. VIRTANEN 1 \\ From the National Public Health Laboratory, Turku, Finland
}

SYNOPSIS One hundred and thirteen strains of motile, Gram-positive, catalase-positive, clusterforming cocci were isolated from patients with urinary infection attending a private surgery. They constituted $1 \%$ of the total 11302 positive cultures. The biochemical characteristics and the drug sensitivities of the strains are described. The significance of motility for organisms which cause urinary infections is pointed out.

At the present time the organisms isolated are orphans in the controversial classification of staphylococci and micrococci.

The classification and nomenclature of staphylococci and micrococci is one of the most confusing examples of taxonomy in microbiology (Baird-Parker, 1965a). The traditional classification according to Bergey's manual (Breed, Murray, and Smith, 1957) has been found unsatisfactory (Shaw, Stitt, and Cowan, 1951; Thatcher and Simon, 1957; Garvie, Higgs, and Neave, 1961; Pohja and Gyllenberg, 1962). Numerous new schemes have been proposed (Shaw et al, 1951 ; Baird-Parker, 1962, 1963, 1965b, and 1966; Gibson, 1967). These suggestions, with their numerous groups, subgroups, and biotypes, have not been sufficient to establish a good general classification. One of the most successful schemes was later labelled as a bad one by the author who constructed it (Cowan, 1971). It is generally agreed that there is a need to separate the mainly parasitic and facultative anaerobic staphylococci from the mainly saprophytic and aerobic micrococci. The problem remains, however, as to the best methods of separation (Baird-Parker, 1965a).

The Subcommittee on Taxonomy of Staphylococci and Micrococci (International Committee on Nomenclature of Bacteria, 1971) favoured the acceptance of four genera of Gram-positive, catalasepositive, and cluster-forming cocci: Staphylococcus rosenbach, Micrococcus cohn, Planococcus migula, and Aerococcus williams, hirsch, and cowan. The genus Aerococcus includes the organisms previously

'Present address: Kansanterveyslaboratorion aluelaboratorio Künamyllynkatu 10, 20520 Turku 52, Finland.

Received for publication 28 January 1974. placed in the genera Aerococcus and Gaffkya. Although the importance of the oxidation-fermentation (F/O) test has been criticized (Gibson, 1967; Mortensen and Kocur, 1967; Møller, Christiansen, and Mortensen, 1973), the Subcommittee considered the standard O/F test still the most reliable method for distinguishing between micrococci and staphylococci. The value of DNA analysis (Mortensen and Kocur, 1967) was considered to need further research.

The coagulase-negative, cluster-forming cocci have been neglected by medical bacteriologists in the past largely because most pyogenic lesions were caused by coagulase-positive Staphylococcus aureus strains, and partly because of the lack of any generally accepted criteria for distinguishing the seemingly numerous varieties of coagulase-negative staphylococci and micrococci. Although these organisms were long recognized as a rare and exceptional cause of infection, it is precisely in recent years that more attention has been paid to their role in various in- ? fections (Quinn, Cox, and Fisher, 1965; Person, Yu, and Washington, 1969; Corse and Williams, 1968; Speller and Mitchell, 1973). The organisms have sometimes been called Staphylococcus albus or Staphylococcus epidermidis, sometimes coagulasenegative staphylococci or micrococci.

These strains have been found to be associated with urinary tract infections (Torres Pereira, 1962; Roberts, 1967; Mitchell, 1968; Mabeck, 1969a). They have been reported to be causative agents in 4 to $14 \%$ of urinary infections (Mabeck, 1969b; Gallagher, Montgomerie, and North, 1965; Torres Pereira, 1962). 


\section{Material and Methods}

Thirty-three thousand nine hundred clean-caught midstream voided urine samples were studied at a private surgery in the years 1969-1973. The urine samples were obtained after carefully washing the external genitalia with soap and sterilized water. Eleven thousand three hundred and two of the cultures were positive. In 113 cases Gram-positive, catalase-positive, phosphatase-negative, coagulasenegative, cluster-forming cocci were isolated. Ninetyfour of the patients were women and 19 were men. The ages of the women varied from 15 to 81 years (mean $34.8 \pm 1.8$ years); that of the men varied from 24 to 75 years (mean $58.8 \pm 1 \cdot 1$ years).

A wet mount of the sample was immediately microscoped for the presence of bacteria and pus cells. Three or more leucocytes per high-power field were considered to indicate pyuria. The sample was Gram-stained and cultured with calibrated loops on a bromocresol purple lactose agar plate, on a $5 \%$ sheep's blood agar plate, and after dilution with saline to $10^{-5}$ on a nutrient agar plate. The loops were calibrated to deliver $0.01 \mathrm{ml}$ and $0.001 \mathrm{ml}$ respectively. A colony count of over $10^{5}$ bacteria $/ \mathrm{ml}$ was taken to indicate true bacteriuria.

The drug sensitivities were determined by Ericsson's disc technique (Ericsson and Sherris, 1971). The discs employed were commercial ones (Biodisc Co), except the $5 \mu \mathrm{g}$ novobiocin discs (Mitchell and Baird-Parker, 1967), which were prepared by the author.
The tests for the free coagulase, and the O/F test for the anaerobic production of acid from glucose were carried out as suggested by the Subcommittee on Taxonomy of Staphylococci and Micrococci (Baird-Parker, 1965c). Urease activity was studied in the Difco (B 272) medium using a heavy inoculum, DNA-ase according to Mortensen and Kocur (1967), and the other biochemical tests were done according to Baird-Parker (1963).

The pigment production was observed first after 24 hours incubation at $37^{\circ} \mathrm{C}$, and later after twodays at room temperature.

The motility was observed in 'hanging-drop' preparations of young cultures in nutrient broth, and checked in Graigie tubes with $0.1 \%$ nutrient agar (Cruickshank, 1969). For the demonstration of flagella Bailey's flagella stain was employed (Society of American Bacteriologists 1957).

\section{Results}

The results of the colony counts and microscopic examination are given in table I. Pyuria was demon-

\begin{tabular}{|c|c|c|c|}
\hline \multirow{2}{*}{$\begin{array}{l}\text { Microscopic } \\
\text { Examination }\end{array}$} & \multicolumn{2}{|c|}{ Bacterial Count (organisms $/ m l$ ) } & \multirow[t]{2}{*}{ Total } \\
\hline & $10^{5}-10^{6}$ & $>10^{\circ}-\geqslant 10^{\circ}$ & \\
\hline $\begin{array}{l}\text { Pyuria + } \\
\text { Pyuria - }\end{array}$ & $\begin{array}{r}8 \\
12 \\
20\end{array}$ & $\begin{array}{l}34 \\
59 \\
93\end{array}$ & $\begin{array}{r}42 \\
71 \\
113\end{array}$ \\
\hline
\end{tabular}

Table I The results of colony counts

\begin{tabular}{|c|c|c|c|}
\hline & Positive & Negative & Total \\
\hline Catalase & 113 & - & 113 \\
\hline Coagulase & - & 113 & 113 \\
\hline DNÄase & 7 & 106 & 113 \\
\hline Egg yolk & 7 & 106 & 113 \\
\hline Phosphatase & - & 113 & 113 \\
\hline Urease & 113 & - & 113 \\
\hline Assimilation of $\mathrm{NH}_{4} \mathrm{H}_{2} \mathrm{PO}_{4}$ & 5 & 108 & 113 \\
\hline Growth at $44^{\circ} \mathrm{C}$ & 62 & 51 & 113 \\
\hline Growth after $1 / 2 \mathrm{hr}$ at $56^{\circ} \mathrm{C}$ & 17 & 96 & 113 \\
\hline Growth on $40 \%$ bile agar & 113 & - & 113 \\
\hline Growth in $10 \% \mathrm{NaCl}$ broth & 113 & - & 113 \\
\hline Motility & 113 & - & 113 \\
\hline Oxidation of glucose & 113 & - & 113 \\
\hline Fermentation of glucose & 33 & 80 & 113 \\
\hline Aerobic acid production from glucose & 113 & - & 113 \\
\hline Aerobic gas production from glucose & - & 113 & 113 \\
\hline \multicolumn{4}{|l|}{ Aerobic acid production from: } \\
\hline Arabinose & - & 113 & 113 \\
\hline Galactose & 113 & - & 113 \\
\hline Inositol & - & 113 & 113 \\
\hline Lactose & 113 & - & 113 \\
\hline Maltose & 113 & - & 113 \\
\hline Mannitol & 75 & 38 & 113 \\
\hline Salicin & 8 & 105 & 113 \\
\hline Gelatine liquefaction & 44 & 69 & 113 \\
\hline Hippurate hydrolysis & 76 & 37 & 113 \\
\hline Voges-Proskauer test & 111 & 2 & 113 \\
\hline
\end{tabular}

Table II Biochemical tests and growth characteristics 
Table III Drug sensitivities

strated in $37.2 \%$. Gram-positive cocci in clusters were always seen in the direct smears made immediately after voiding.

Slightly yellowish pigment was formed by 25 strains; 88 strains were ivory. All strains were motile. The motility in culture media employed was not as fast as that of enterobacteria, but was generally demonstrated within a week. Young cultures of

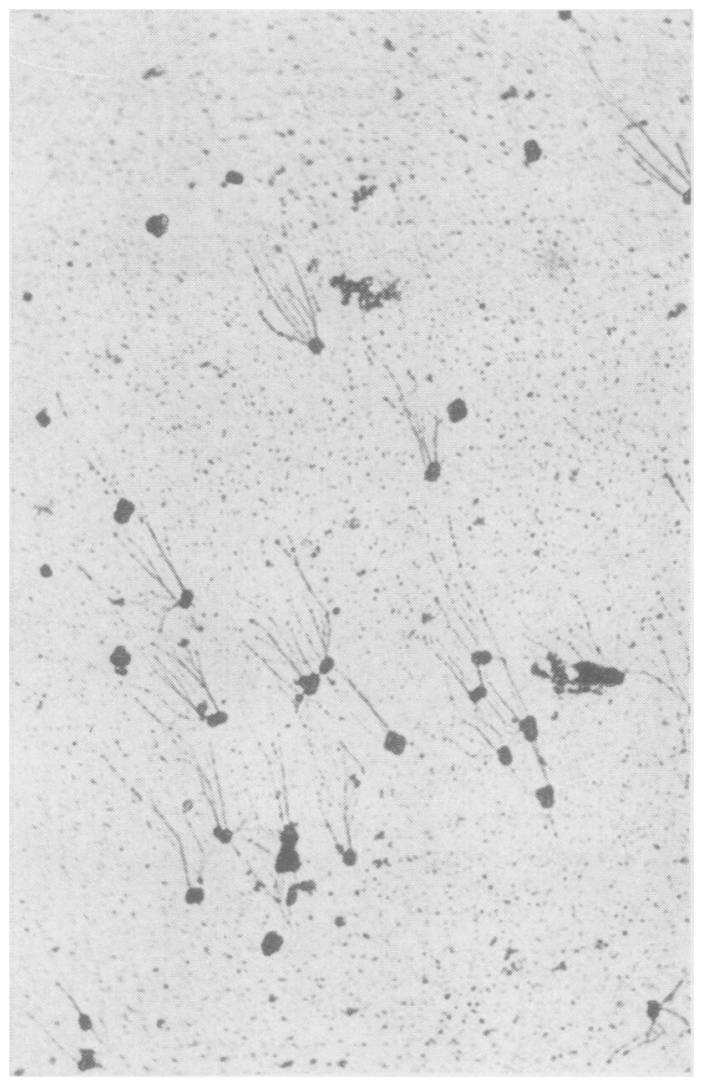

Fig 1 Flagellated cluster-forming cocci. Staining by Bailey's method, 1200. recently isolated strains showed a lively motility in 옹 'hanging-drop' preparations.

The growth characteristics and the results of ir biochemical tests are shown in table II, and drug sensitivities in table III.

Motile cultures examined by the Bailey stain showed 1-2 flagella (fig 1). An electron micrograph is shown in figure 2 .

\section{Discussion}

The occurrence of bacteria in direct mounts and Gram-stained smears and high colony counts of a single strain, fairly frequent pyuria, and the simultaneously occurring clinical symptoms justify with reasonable certainty regarding these organisms as causative agents of infection. Only one sample was obtained from each patient, because the treatment could not be postponed for dysuria, frequent urination, or other clinical symptoms and signs.

The Gram-positive, catalase-positive, and clusterforming cocci isolated from the cases of urinary infection do not seem to constitute a homogeneous group. Their biochemical characteristics and their drug sensitivities vary. However, the two common characteristics (motility and urease activity) might be useful for an organism causing urinary infection. The vast majority of urinary infections are caused by motile microorganisms ascending the urinary passages, eg, enterobacteria and enterococci.

From the taxonomical point of view the organisms isolated present a dilemma. They do not fit any of the groups presently proposed (International Committee on Nomenclature of Bacteria, 1971) for the classification of micrococci and staphylococci. At present the motile micrococci are placed in the genus Planococcus migula. The characteristics of the genus Planococcus migula were rather vaguely described by the original author (Migula, 1894 and 1900). Kocur, Páčoba, Hodgkiss, and Martinez (1970) described in more detail the characteristics of the flagellated marine cocci placed in the genus Planococcus. Their strains did not produce acid from glucose, did not 


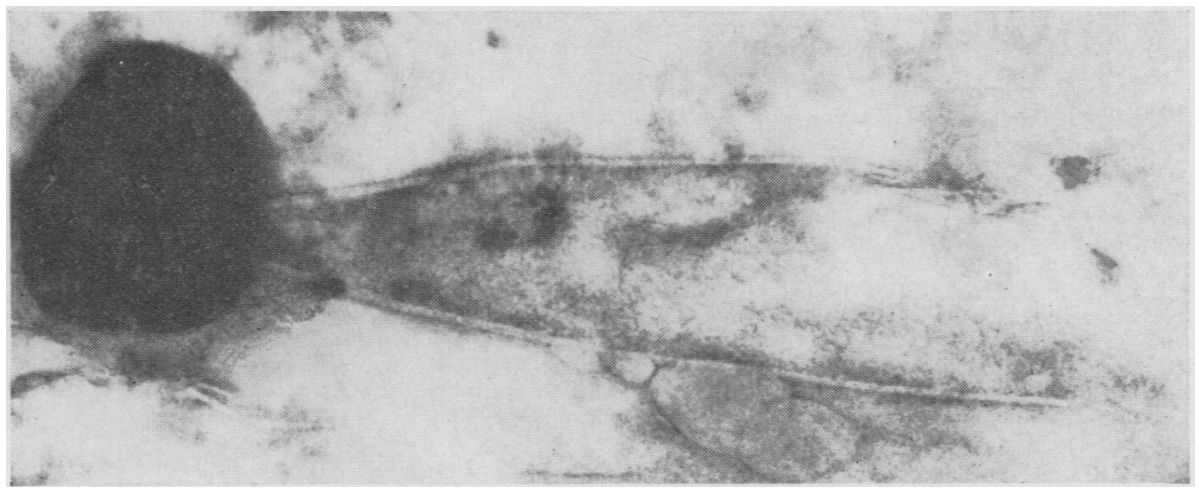

produce acetoin, and were distinctly pigmented. The strains isolated by the author do not correspond to any of the seven species described by Migula (1900). At present the organisms are orphans in the taxonomy of staphylococci and micrococci.

The organisms studied were isolated in the course of five years from 33900 samples taken from outpatients. Eleven-thousand three-hundred and three of the samples were positive on culture, and the vast majority were various enterobacteria. Thus, the organisms of the present study constitute only $1 \%$ of the total. Consequently they seem to be a rare cause of urinary infection, and therefore may be sometimes wrongly regarded as unimportant contaminants. This is especially the case when they occur simultaneously with contaminant flora. A meticulous and careful technique in obtaining urine samples is extremely important and cannot be overemphasized.

Gram-positive, catalase-positive, and clusterforming cocci have been isolated from the cases of urinary infection by several authors (Mortensen, 1969; Roberts, 1967; Mitchell, 1968; etc). They form a heterogeneous group containing staphylococci and micrococci. The strains reported by Mortensen (1969) were non-motile, but usually the motility has not been mentioned by the authors.

Obviously the strains isolated do not fit well into the present taxonomy but do so better in vivo. Anyway they form a 'minority group' which is easily overloooked. It is likely that their small but definite role will be more clearly defined in the future.

\section{References}

Baird-Parker, A. C. (1962). The occurrence and enumeration, according to a new classification, of micrococci and staphylococci in bacon and on human and pig skin. J. appl. Bact., 25, 352-361.

Baird-Parker, A. C. (1963). A classification of micrococci and staphylococci based on physiological and biochemical tests. J. gen. Microbiol., 30, 409-427.
Baird-Parker, A. C. (1965a). Staphylococci and their classification Ann. N.Y. Acad. Sci., 128, 4-25.

Baird-Parker, A. C. (1965b). The classification of staphylococci and micrococci from world-wide sources. J. gen. Microbiol., 38, 363-387.

Baird-Parker, A. C. (1965c). Recommendations of the Subcommittee on taxonomy of staphylococci and micrococci. Int. Bull. bact. Nomencl., 15, 109-110.

Baird-Parker, A. C. (1966). Methods for classifying staphylococci and micrococci. In Identification methods for Microbiologists, Pt A (Society for Applied Bacteriology, Technical Series, No. 1), edited by B. M. Gibbs and F. A. Skinner, pp. 59-64. Academic Press, London and New York.

Breed, R. S., Murray, E. G. D., and Smith, N. R. (1957). Bergey's Manual of Determinative Bacteriology, 7th ed. Bailliere, Tindall, and Cox, London.

Corse, J., and Williams, R. E. O. (1968). Antibiotic resistance of coagulase-negative staphylococci and micrococci. J. clin. Path., 21, 722-728.

Cowan, S. T. (1971). Sense and nonsense in bacterial taxonomy. J. gen. Microbiol., 67, 1-8.

Cruickshank, R., ed., (1969). Medical Microbiology, 11th ed., p. 235. Livingstone, Edinburgh and London.

Ericsson, H. M., and Sherris, J. C. (1971). Antibiotic sensitivity testing. Acta. path. microbiol. scand., Sect. B, Suppl. 217.

Gallagher, D. J. A., IMontgomerie, J. Z., and North, J. D. K. (1965). Acute infections of the urinary tract and the urethral syndrome in general practice. Brit. med. J., 1, 622-626.

Garvie, E. I., Higgs, T. M., and Neave, F. K. (1961). Unusual varieties of Staphylococcus aureus. J. Path. Bact., 81, 255-259.

Gibson, T. (1967). The status of the genus Micrococcus. Int. J. system. Bact., 17, 231-233.

International Committee on Nomenclature of Bacteria, Subcommittee on Taxonomy of Staphylococci and Micrococci (1971). Minutes of meeting held 2/3 April 1968. Int. J. system. Bact., 21, 161-164.

Kocur, M., Pácova, Z., Hodgkiss, W., and Martinec, T. (1970). The taxonomic status of the genus Planococcus Migula 1894. Int. J. system. Bact., 20, 241-248.

Mabeck, C. E. (1969a). Studies in urinary tract infections. II. Urinary tract infection due to coagulase-negative staphylococci. Acta med. scand., 186, 39-45.

Mabeck, C. E. (1969b). Significance of coagulase-negative staphylococcal bacteriuria. Lancet, 2, 1150-1152.

Migula, W. (1894). Ueber ein neues System der Bakterien. Arb. bakt. Inst. Karlsruhe, 1, 235-238.

Migula, W. (1900). System der Bakterien, 269. Fischer, Jena.

Mitchell, R. G. (1968). Classification of Staphylococcus albus strains isolated from the urinary tract. J. clin. Path., 21, 93-96.

Mitchell, R. G., and Baird-Parker, A. C. (1967). Novobiocin resistance and the classification of staphylococci and micrococci. J. appl. Bact., 30, 251-254. 
Mortensen, N. (1969). Studies in urinary tract infections III. Biochemical 'characteristics of coagulase-negative staphylococci associated with urinary tract infections. Acta med. scand. 186, 47-51.

Mortensen, N., and Kocur, M. (1967). Correlation of DNA base composition and acid formation from glucose of staphylococci and micrococci. Acta. path. microbiol. scand., 69, 445-457.

Møller, J. K., Cristiansen, C., and Mortensen, N. (1973). DNA base composition of coagulase negative staphylococci associated with urinary tract infection. Acta path. microbiol. scand., Sect. B., 81, 559-562.

Person, D. A., Yu, P. K. W., and Washington, J. A. II (1969). Characterization of Micrococcaceae isolated from clinical sources. Appl. Microbiol., 18, 95-97.

Pohja, M. S., and Gyllenberg, H. G. (1962). Numerical taxonomy of micrococci of fermented meat origin. J. appl. Bact., 25, 341-351.

Quinn, E. L., Cox, F., and Fisher, M. (1965). The problem of associ-

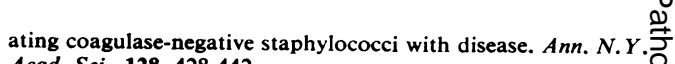
Acad. Sci., 128, 428-442.

Roberts, A. P. (1967). Micrococcaceae from the urinary tract in pregnancy. J. clin. Path., 20, 631-632.

Shaw, C., Stitt, J. M., and Cowan, S. T. (1951). Staphylococci and their classification. J. gen. Microbiol., 5, 1010-1023.

Society of American Bacteriologists (1957). Manual of Microbiological Methods, pp. 27-28. McGraw-Hill, New York

Speller, D. C. E., and Mitchell, R. G. (1973). Coagulase negative $\overline{\bar{T}}$ staphylococci causing endocarditis after cardiac surgery. J. clin. Path., 26, 517-522.

Thatcher, F. S., and Simon, W. (1957). Some physiological and toxigenic properties of members of the genus Micrococcus in rela- tion to taxonomy. Int. Bull. bact. Nomencl., 7, 21-36.

Torres Pereira, A. (1962). Coagulase-negative strains of staphylococcus possessing antigen 51 as agents of urinary infection. J. clin. $\overrightarrow{\mid \overrightarrow{ }}$ Path., 15, 252-253.

\section{The April 1974 Issue}

\section{THE APRIL 1974 ISSUE CONTAINS THE FOLLOWING PAPERS}

Chemotherapy of experimental streptococcal endocarditis Part III Failure of a bacteriostatic agent (tetracycline) in prophylaxis FREDERICK $\mathrm{s}$. SOUTHWICK AND DAVID T. DURACK

An improved test for Haemophilus influenzae precipitins in the serum of patients with chronic respiratory disease JUDITH L. DAVIES, CHRISTIAN R. LAUGHTON, AND J. ROBERT MAY

The effect of minocycline on Candida albicans PAMELA M. WATERWORTH

An experimental assessment of different anaerobic blood culture methods $\quad$ D. C. SHANSON

A comparison of media used in vitro to isolate nonsporing Gram-negative anaerobes from blood W. R. FORGAN-SMITH AND J. H. DARRELL

Chlorhexidine resistance in Proteus mirabilis D. J. STICKLER

Membrane filtration in the study of antimicrobial drugs P. D. MEERS AND GILLIAN M. CHURCHER

A comparative study of viruses associated with acute haemorrhagic conjunctivitis P. G. HIGGINS, R. J. SCOTT, PATRICIA M. DAVIES, AND D. R. GAMBLE

The relationship between urinary infection, cystoscopic appearance, and pathology of the bladder in man

I Lymphocytes in the lamina propria

II Squamous change in the bladder epithelium

F. P. MARSH, R. BANERJEE, AND P. PANCHAMIA
Disseminated histoplasmosis successfully treated ${ }^{\infty}$ with amphotericin B R. P. S. EDMONSON, SUSANNAH EYKYN, D. R. DAVIES, I. W. FAWCETT, AND IAN PHILLIPS Mucin histochemistry of mucous carcinomas of breast and colon and non-neoplastic breast epi- $\vec{\varphi}$ thelium D. J. COOPER

Changes in composition of mucin in the mucosa adjacent to carcinoma of the colon as compared with the normal: A biochemical investigation M. I. FILIPE AND K. B. COOKE

Iodine contamination of the serum protein-bound iodine: Incidence and clinical significance P. R. 3 PANNALL, P. C. MINNAAR, AND A. T. NESER

Antibody to hepatitis B antigen in haemophiliacs and their household contacts C. J. BURRELL, A. C.? PARKER, D. M. RAMSAY, AND ELAINE PROUDFOOT

The effect of age on the fibrinolytic enzyme system $\delta$ P. J. HAMILTON, AUDREY A. DAWSON, D. OGSTON, AND A. S. DOUGLAS

A system for data processing in haematology $\frac{7}{0}$ I. CAVILL, C. RICKETTS, T. MOULDING, A. JACOBS, AND M. PAGE

Training of pathologists by a system of modules JOHN STUART AND PHILIP A. GORDON

Technical method

Demonstration lymphocyte nucleoli $\quad$ J. C. RIDWAY AND J. V. GARRETT

Letter to the Editor

Book reviews

Copies are still available and may be obtained from the PUBLISHING MANAGER, BRITISH MEDICAL ASSOCIATION, TAVISTOCK SQUARE, LONDON, WC1H 9JR, price $£ 1.05$. 